Annals of Warsaw University of Life Sciences - SGGW

Land Reclamation No 38, 2007: 19-24

(Ann. Warsaw Univ. of Life Sci. - SGGW, Land Reclam. 38, 2007)

\title{
Heavy metal content in soil and consumption yield in the vicinity of petrochemical plant*
}

\author{
ZBIGNIEW M. KARACZUN, LEONARD INDEKA, GRAŻYNA OBIDOSKA \\ Department of Environment Protection \\ Warsaw University of Life Sciences - SGGW
}

\begin{abstract}
Heavy metal content in soil and consumption yield in the vicinity of petrochemical plant. The research on soil and consumption yield quality at the impact zone of the petrochemical plant in Płock (ZRiP), conducted in the 1970s and 80 s, proved that the emissions from the plant threatened the agricultural production within the area. As the emission levels from the ZRiP have significantly dropped in recent years, analyses were conducted in order to assess the current content of $\mathrm{Cd}, \mathrm{Cr}, \mathrm{Cu}, \mathrm{Ni}, \mathrm{Pb}$ and $\mathrm{Zn}$ in soils as well as in wheat grain and potato tuber cultivated within the area. The results showed that the soils were not contaminated with above mentioned heavy metals, but the level of cadmium was exceeded in potato tubers collected from three research points and in wheat grain collected from one point.
\end{abstract}

Key words: soil contamination, consumption yield contamination, heavy metals.

\section{INTRODUCTION}

Apart from transport and municipal services, industrial plants constitute the main source of heavy metals released to environment (Kabata-Pendias, Pendias, 1993; Hjortenkrans et al., 2006). A higher metal content in soils occurs most frequently within urbanized areas (Singh, Kumar, 2006) and around industrial facilities (Li et al., 2006; Shukurov et al., 2006). The petrochemical and refinery sector is counted among significant sources of environmental pollution, with an impact on inter alia the state of soils and the content of pollutants in the plants cultivated on these soils (Gogoi et al., 2003; Hassan et al., 2005; Jamrah et al., 2007).

The refinery and petrochemical plant in Płock - ZRiP (Zakłady Rafineryjne i Petrochemiczne Orlen S.A. w Płocku) is the largest petrochemical unit in Poland. The facility, opened in the 1960s, was constructed amidst agricultural areas. The analysis of agricultural areas around the facility, conducted in the 1970s and 80 s, showed that the plant constituted the most important source of pollution for soils and agricultural produce cultivated within its vicinity (Indeka, 1991; Indeka and Stawicka, 1991; Karaczun, 1991). In the 1990s and at the beginning of the $21^{\text {st }}$ century the plant implemented a number of investments aimed at lowering the pollutant load released to environment. There is however no information whether the investments were successful in raising the level of security for agricultural production within the area.

The research was undertaken to verify whether the content of the selected heavy metals, in the soil of agricultural areas located in the vicinity of the ZRiP, threatens the agricultural production and

\footnotetext{
*The work has been supported by the SGGW internal research grant.
} 
whether it depends on the distance from the plant. Moreover, the aim of the study was to check if the content of heavy metals in selected consumption yields (wheat grain and potato tuber) poses any threat to consumers.

\section{METHODS}

The research was conducted within agricultural areas located in the vicinity of the refinery and petrochemical plant in Płock. Soil and plant samples were collected in two transects:

- In the north-eastern direction from the facility (the main wind direction), with five research points (area about $10 \mathrm{ha}$ ): I - $1 \mathrm{~km}$ from the ZRiP, II - 3 $\mathrm{km}, \mathrm{III}-6 \mathrm{~km}, \mathrm{IV}-12 \mathrm{~km}$ and V $-18 \mathrm{~km}$;

- In the south-western direction, with research points at the distance of 3 $\mathrm{km}$ (point VI) and $6 \mathrm{~km}$ (point VII) from the facility.

The arable soil layers from which the samples were collected had the following granulometric composition and $\mathrm{pH}$ in $\mathrm{H}_{2} \mathrm{O}$ : (1) - glp, 6.0; (2) - glp, 6.4; (3) - glp, 5.9; (4) - pgmp, 6.0; (5) - glp, 5.7; (6) - gl, 6.4; (7) - pglp, 6.0* .

Soil samples (20-30 individual samples from one research point) were collected by means of an Egner's sampling stick from the arable layer of soil at the break of July and August 2006. The samples were collected in several places within a research point and mixed together in order to obtain an average sample. The soil was next dried at a room temperature until it reached the air dry state, mineralized in an acid mixture and analyzed for the content of: cadmium, lead, copper, chromium, zinc and nickel.

Plant samples $\quad(20-30$ individual samples from one research point) were collected in two terms: cereals at the harvest period (break of July and August 2006) and the potato tubers in September 2006. The grain was threshed and the potatoes were peeled and both dried at the temperature of $105^{\circ} \mathrm{C}$ and shredded in a rotation mill. The samples were mineralized basing on PB Vol. 3 of 25 May 2005. A mixture of nitric acid (65\%) and perhydrol (30\%), by Merck was used for mineralization. The heavy metal content - both in soil and in plants - was measured by means of the atomic absorption spectrophotometry, using SOLAAR (UNICAM) spectrometer furnace. For $\mathrm{Ni}, \mathrm{Cu}$ and $\mathrm{Zn}$ flame atomization; for $\mathrm{Pb}$, $\mathrm{Cr}$ and $\mathrm{Cd}$ electrothermal atomization.

\section{RESULTS AND DISCUSSION}

The content of heavy metals in soil influences the possibilities for its agricultural use. In order to assess agricultural usability, this content should be compared with the recommendations issued by the State Environmental Protection Inspection and the Institute of Soil Science and Plant Cultivation (Kabata-Pendias et al., 1995). According to this classification, the soils analysed (Fig. 1) fall into the category of not contaminated soils with a natural heavy metal content. Such soils can be used for all types of agricultural and horticultural

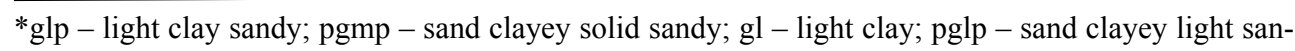
dy. 

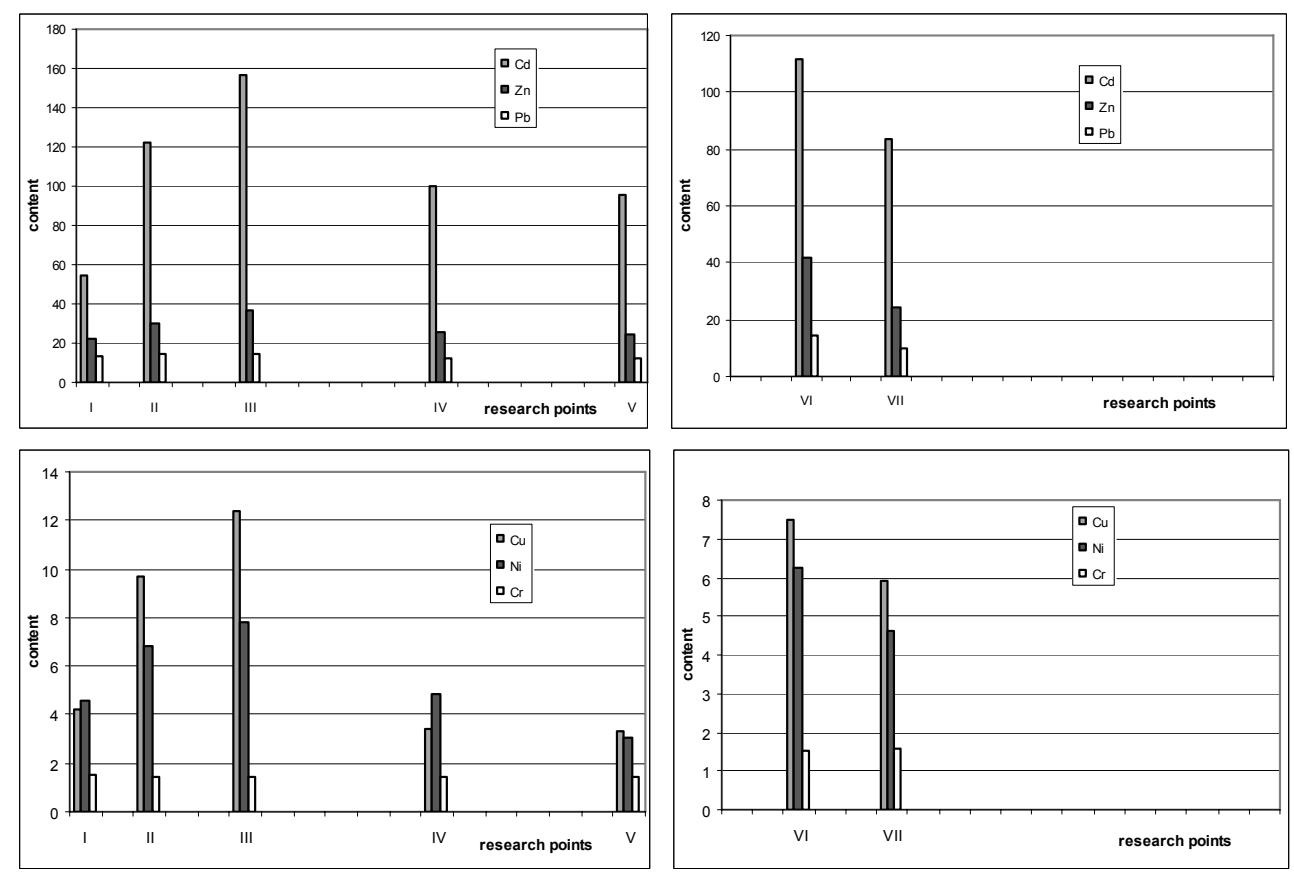

FIGURE 1 . Heavy metals content ( $\mathrm{Cd}$ in $\mu \mathrm{g} / \mathrm{kg}$ of d.m., remaining in $\mathrm{mg} / \mathrm{kg}$ of d.m.) in soil samples collected in 7 research points situated at different distances from petrochemical plant in Płock

crops, in line with the rules on a rational usage of agricultural production space.

Moreover, a comparison of the heavy metal content in the analysed soils with the permissible values (as specified by environmental protection bodies - State Environmental Protection Inspection 1994) shows that there are no contraindications for developing different types of horticultural and agricultural production within this area.

In order to judge whether the content of heavy metals in plants (wheat grain and potato tuber) does not pose a threat to consumer health, the results were compared with the permissible values defined in the Regulation of the Minister of Health (DzU 9/2001 item 72). Although due to recent changes in the legislation (adoption of a new act on food and nutrition safety), the regulation is not binding anymore, the permissible values for heavy metal content in foodstuffs that it defines may be judged as reliable indices for food safety. From among the analysed metals, the regulation specifies values for lead, cadmium and zinc. The lead content in wheat grain (Tab. 1) and potato tubers (Tab. 2) was lower than the maximum permissible level in all the samples. The content of zinc in potato tuber was seemingly exceeded in all the samples, however, considering the $77 \%$ water content in tubers (Produkty spożywcze... 1990) these values become safe to consumer health (permissible level $-10 \mathrm{mg} / \mathrm{kg}$ of fresh mass). A comparison of cadmium content in potato tubers with the permissible levels for this metal (up to $0.05 \mathrm{mg} / \mathrm{kg}$ of fresh 
TABLE 1. Heavy metal content in wheat grain collected in 7 research points in the vicinity of petrochemical plant in Płock

\begin{tabular}{|l|c|c|c|c|c|c|}
\hline $\begin{array}{l}\text { Research } \\
\text { points }\end{array}$ & $\begin{array}{c}\text { Lead } \\
(\mu \mathrm{g} / \mathrm{kg})\end{array}$ & $\begin{array}{c}\text { Cadmium } \\
(\mu \mathrm{g} / \mathrm{kg})\end{array}$ & $\begin{array}{c}\text { Copper } \\
(\mathrm{mg} / \mathrm{kg})\end{array}$ & $\begin{array}{c}\text { Chromium } \\
(\mu \mathrm{g} / \mathrm{kg})\end{array}$ & $\begin{array}{c}\text { Zinc } \\
(\mathrm{mg} / \mathrm{kg})\end{array}$ & $\begin{array}{c}\text { Nickel } \\
(\mathrm{mg} / \mathrm{kg})\end{array}$ \\
\hline I & 38.29 & 77.16 & 1.93 & 409.84 & 30.23 & 0.00 \\
\hline II & 32.97 & 48.90 & 2.84 & 185.56 & 27.73 & 0.00 \\
\hline III & 40.87 & 87.24 & 1.10 & 372.88 & 22.68 & 0.00 \\
\hline IV & 30.00 & 97.86 & 1.92 & 253.77 & 27.85 & 0.00 \\
\hline V & 32.46 & 171.34 & 2.52 & 190.09 & 52.12 & 0.27 \\
\hline VI & 39.39 & 45.52 & 2.87 & 260.00 & 31.49 & 0.00 \\
\hline VII & 31.51 & 62.01 & 3.63 & 325.18 & 35.33 & 0.37 \\
\hline
\end{tabular}

TABLE 2. Heavy metal content in potato tubers collected in 7 research points in the vicinity of petrochemical plant in Płock

\begin{tabular}{|l|c|c|c|c|c|c|}
\hline $\begin{array}{l}\text { Research } \\
\text { points }\end{array}$ & $\begin{array}{c}\text { Lead } \\
(\mu \mathrm{g} / \mathrm{kg})\end{array}$ & $\begin{array}{c}\text { Cadmium } \\
(\mu \mathrm{g} / \mathrm{kg})\end{array}$ & $\begin{array}{c}\text { Copper } \\
(\mathrm{mg} / \mathrm{kg})\end{array}$ & $\begin{array}{c}\text { Chromium } \\
(\mu \mathrm{g} / \mathrm{kg})\end{array}$ & $\begin{array}{c}\text { Zinc } \\
(\mathrm{mg} / \mathrm{kg})\end{array}$ & $\begin{array}{c}\text { Nickel } \\
(\mathrm{mg} / \mathrm{kg})\end{array}$ \\
\hline I & 0 & 190.34 & 5.94 & 129.61 & 25.58 & 0 \\
\hline II & 0 & 301.88 & 8.61 & 62.89 & 20.88 & 0.08 \\
\hline III & 0 & 155.10 & 9.26 & 141.80 & 24.42 & 0.38 \\
\hline IV & 0 & 252.46 & 5.67 & 97.42 & 19.32 & 0 \\
\hline V & 0 & 243.21 & 2.34 & 80.10 & 22.25 & 0 \\
\hline VI & 0 & 143.71 & 6.05 & 47.72 & 25.55 & 0 \\
\hline VII & 0 & 78.54 & 4.63 & 98.80 & 20.52 & 0 \\
\hline
\end{tabular}

mass) shows that these levels have been exceeded in three research points: II, IV and $\mathrm{V}$ (even when the water content is taken into consideration).

The maximum permissible level for cadmium content $(0.10 \mathrm{mg} / \mathrm{kg}$ of fresh mass) in wheat grain was exceeded in the $\mathrm{V}$ research point (having accounted for the $13 \%$ grain moisture). Also earlier research within this area showed that the cadmium content in potato tuber and wheat grain was exceeded at a similar level (Indeka, 1996).

No direct correlation has been identified between the content of the analysed metals in the soil and plants (Tab. 3) and the distance of research points from the ZRiP. The content of all the analysed metals in the samples collected from the transect located at north-eastern direction increases between $1-6 \mathrm{~km}$ and then falls $(6-18 \mathrm{~km})$. Another tendency has been observed in the samples collected within the south-western direction from the ZRiP - the metal content diminishes as the distance increases. There is no common trend for the changes in the metal content in plants. Almost each analysed metal follows its own individual pattern of changes. Only the copper content in potato tuber and the lead content 
TABLE 3. Levels of the correlation coefficient between the heavy metal content in soil and in the consumption yield*

\begin{tabular}{|l|c|c|c|c|c|c|}
\hline & Lead & Cadmium & Copper & Chromium & Zinc & Nickel \\
\hline Wheat grain & 0.6612 & -0.0862 & -0.0253 & 0.5 & -0.3911 & nd \\
\hline Potato tuber & nd & 0.0978 & 0.8535 & 0.0682 & 0.4646 & nd \\
\hline
\end{tabular}

$*$ the value of the tabular correlation coefficient $r=0.6664$, for $\alpha=0.05$.

in wheat grain changed similarly to the content of these metals in soil.

\section{CONCLUSIONS}

1. All of the analysed soils, in the vicinity of petrochemical plant in Płock, can be judged as not contaminated with heavy metals. Their content in soils may be considered natural.

2. No clear tendency concerning changes of analysed heavy metals content in soils with the increasing distance from petrochemical plant has been identified. This appears to prove that the plant does not constitute the main source of heavy metals in soils in the area.

3. The content oflead, copper, chromium and nickel in all the analysed samples of wheat grain and potato tuber was lower than the permissible levels.

4. The permissible level of cadmium content was exceeded in potato tubers from three research points and in wheat grain from one point.

5. A significant statistical correlation between the heavy metal content in soil and consumption yield has been identified for copper in potato tuber. Such statistically viable correlation has not been found for any other metal analysed.

\section{REFERENCES}

GOGOI B.K., DUTTA N.N., GOSWAMI P., MOHAN T.R. 2003: A case study of bioremediationofpetroleum-hydrocarbon contaminated soil at a crude oil spill site. Advances in Environmental Research, 7, 767-782.

HASSAN H., TAHA R., AL-RAWAS A., AL-SHANDOUDI B., AL-GHEITHI K., AL-BARAMI A. 2005: Potential uses of petroleum-contaminated soil in highway construction. Construction and Building Materials, 19, 646-652.

HJORTENKRANS D., BERGBACK B., HAGGERUD A. 2006: New metal emission patterns in road traffic environments Environmental Monitoring and Assessment (2006) 117: 85-98

INDEKA L. 1991: Wpływ MZRiP na środowisko przyrodnicze Cz. I. Skażenie powietrza, wody i gleby. Biul. IHAR 177; 195-203.

INDEKA L. 1996: Chemiczne skażenia wybranych roślin uprawianych $\mathrm{w}$ rejonie oddziaływania Mazowieckich Zakładów Rafineryjnych i Petrochemicznych. Seria: Rozprawy Naukowe i Monografie. Wyd. SGGW, Warszawa.

INDEKA L., STAWICKA J. 1991: Wpływ MZRiP na środowisko przyrodnicze. $\mathrm{Cz}$. II. Wpływ na rośliny, zwierzęta i człowieka. Biul. IHAR 177; 205-213.

JAMRAH A., AL-FUTAISI A., HASSAN H., AL-ORAIMI S. 2007: Petroleum contaminated soil in Oman: Evaluation of bioremediation treatment and potential for reuse in hot asphalt mix concrete. 
Environmental Monitoring Assessment 124: 331-341

KABATA-PENDIAS A., PIOTROWSKA M., MOTOWICKA-TERELAK T., MALISZEWSKA-KORDYBACH B., FILIPIAK K., KRAKOWIAK A., PIETRUCH C. 1995: Podstawy oceny chemicznego zanieczyszczenia gleb. Metale ciężkie, siarka i WWA. PIOŚ, IUNiG, Warszawa.

KABATA-PENDIAS A., PENDIAS H. 1993: Pierwiastki śladowe w środowisku biologicznym. Wyd. Geologiczne, Warszawa.

KARACZUN Z. 1991: Wpływ przemysłu rafineryjno-petrochemicznego na poziom akumulacji metali ciężkich i siarki oraz aktywność biologiczną niektórych enzymów w użytkowanych rolniczo glebach okolic Płocka. Praca doktorska. Maszynopis SGGW. Warszawa.

LI J., XIE Z.M., XU J.M., SUN Y.F. 2006: Risk assessment for safety of soils and vegetables around a lead/zinc mine Environmental Geochemistry and Health (2006) 28: 37-44.

PIOŚ 1994: Wskazówki metodyczne do oceny stopnia zanieczyszczenia gruntów i wód podziemnych produktami ropopchodnymi i innymi substancjami chemicznymi w procesach rekultywacji. PIOŚ, Warszawa.

Rozporządzenie Ministra Zdrowia $\mathrm{z}$ dnia 27 grudnia 2000 roku w sprawie wykazu dopuszczalnych ilości substancji dodatkowych i innych substancji obcego pochodzenia dodawanych do środków spożywczych lub używek, a także zanieczyszczeń, które moga znajdować się w środkach spożywczych lub używkach. DzU nr 9 z 2001 roku poz. 72.
SHUKUROV N., PEN-MOURATOV S., STEINBERGER Y. 2006: The impact of the Almalyk Industrial Complex on soil chemical and biological properties. Environmental Pollution 136 (2005) 331-340.

SINGH S., KUMAR M. 2006: Heavy metal load of soil, water and vegetables in periurban Delhi. Environmental Monitoring and Assessment (2006) 120: 79-91.

Streszczenie: Zawartość wybranych metali ciężkich $w$ glebie i plonie konsumpcyjnym $w$ sqsiedztwie zaktadów rafineryjno-petrochemicznych $w$ Plocku. Prowadzone $\mathrm{w}$ latach siedemdziesiątych i osiemdziesiątych badania jakości gleb i plonu konsumpcyjnego w strefie oddziaływania płockiej petrochemii wskazywały, że emisje $\mathrm{z}$ tego zakładu stanowią zagrożenie dla możliwości prowadzenia na tym terenie działalności rolniczej. Ponieważ wielkość emisji z ZRiP $\mathrm{w}$ ostatnich latach istotnie zmniejszyła się przeprowadzono badania mające na celu ocenę poziomu zawartości $\mathrm{Cd}, \mathrm{Cr}, \mathrm{Cu}, \mathrm{Ni}, \mathrm{Pb}$ i $\mathrm{Zn}$ w glebach położonych w sąsiedztwie tego zakładu oraz w ziarnie pszenicy i bulwach ziemniaków tam uprawnianych. Otrzymane wyniki wskazują, że gleby tego rejonu nie są zanieczyszczone badanymi metalami ciężkimi i może na nich być prowadzony każdy rodzaj produkcji ogrodniczej i rolniczej. W przypadku zawartości analizowanych pierwiastków metalicznych w plonie konsumpcyjnym stwierdzono nadmierną ilość cynku w bulwach ziemniaków (we wszystkich próbach) i ziarnie pszenicy ( $w$ jednej próbce).

MS. received November 2007

\section{Authors' address:}

Katedra Ochrony Środowiska SGGW

02-779 Warszawa

Nowoursynowska 159

Poland 